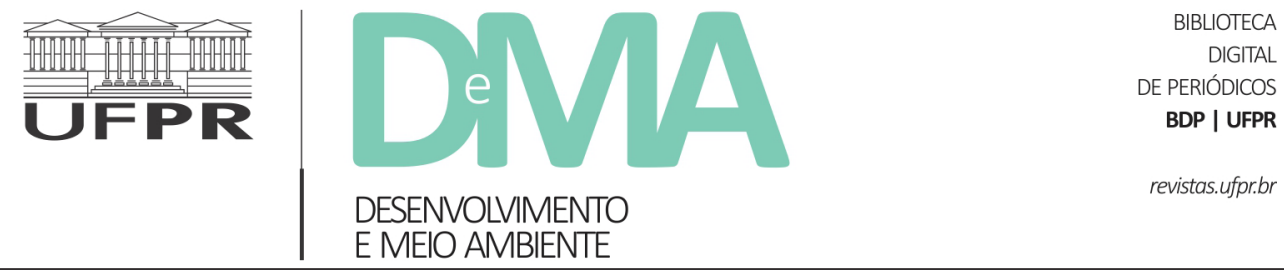

\title{
Residential water demand analysis
}

\section{Análise residencial da demanda de água} \author{
PAULA $^{3}$, Eder Pereira MIGUEL ${ }^{2}$ \\ ${ }^{1}$ Universidade Federal dos Vales do Jequitinhonha e Mucuri (UFVJM), Teófilo Otoni, MG, Brasil \\ ${ }^{2}$ Universidade de Brasília (UnB), Brasília, DF, Brasil. \\ ${ }^{3}$ Universidade Estadual do Centro-Oeste (UNICENTRO), Guarapuava, PR, Brasil. \\ *E-mail of contact: alexalmeida@unb.br
}

Raquel de Souza POMPERMAYER ${ }^{1}$, Humberto ANGELO ${ }^{2}$, Alexandre Nascimento de ALMEIDA ${ }^{2 *}$, Pedro Guilherme de Andrade VASCONCELOS ${ }^{2}$, Eraldo Aparecido Trondoli MATRICARDI ${ }^{2}$, Maristela Franchetti de

Article received on February 22, 2020, final version accepted on June 23, 2020, published on November 16, 2020.

ABSTRACT: This paper presents an estimate of the water demand in Distrito Federal, a Federative Unit of Brazil where the capital of Brazil is located. We develop a water demand model based on the tariff structure to capture the essential aspects of water use by companies and by consumers. For water companies, knowledge of the demand curve provides necessary information needed to set rates that promote an increase in their revenues. For consumers, knowledge of the evolution of water prices is important for the formulating of policies to rationalize consumption. We analyze the residential water demand behavior in two categories of consumers: normal and popular. The demand for water in the study was inelastic in relation to price and income for both the normal and popular customer categories.

Keywords: water market; water policy; econometrics; water scarcity.

RESUMO: $\quad$ Este artigo apresenta uma estimativa da demanda de água no Distrito Federal, uma Unidade da Federação onde a capital do Brasil está localizada. Desenvolveu-se um modelo de demanda baseado na estrutura tarifária para capturar os aspectos essenciais do uso da água pelas empresas e pelos consumidores. Para as empresas de água, o conhecimento da curva de demanda fornece informações necessárias para a definição de tarifas, informação importante para o aumento de suas receitas. Para os consumidores, o conhecimento da evolução dos preços da água é importante para a formulação de políticas de racionalização do consumo. Analisou-se o comportamento da demanda residencial de água em duas categorias de consumidores: normal e popular. A demanda por água no estudo foi inelástica em relação ao preço e a renda para as categorias de clientes normal e popular.

Palavras-chave: mercado de água; política de água; econometria; escassez de água. 


\section{Introduction}

Today, more than a billion people lack adequate access to drinking water and the short-term forecast is that $40 \%$ of the world population will live in regions affected by hydric stress (Jacobi et al., 2016). The authors relate the unsustainability in the supply of water to two aspects: climatic disasters (droughts, floods) and the pollution of water sources. About water governance, Jacobi et al. (2016, p. 1) highlights as important:

[...] analyze water governance, comprising not only its management aspects, but the usage as a natural resource which tackles sustainability from a social point of view as well. Therefore, engagement of new social actors must be broadened, from its management to its use and appropriation. For governance processes to materialize, we need to create suitable conditions, such as inclusion, accountability, participation, transparency, predictability, and response capacity. One of the greatest challenges regarding water governance is to ensure an open and transparent approach, which is also inclusive and communicative, coherent and integrative, equitable and ethical.

Early estimates for water demand assumed that population growth and the type of urban development were the only relevant factors capable of explaining the quantity of water needed. Therefore, water prices and consumers' income were presumed not to affect water demand. However, in the last decades, using prices as a consumption management tool has captured the attention of managers and executives from public as well as private companies. As a matter of fact, recent empirical investigations
(Schleich \& Hillenbrand, 2009; Klaiber et al., 2014; Yoo et al., 2014) of complicated billing structures have explored the effects of price on residential water demand.

A way to improve consumers' perception of the economic value of water is by using taxes that reflect not only the economic but also the environmental costs. On the other hand, there is a deep concern about how much low-income customers should pay for water. In this sense, adopting appropriate tax policies is vital for encouraging water rationalization and promoting more progressive tax systems. Moreover, such policies aim to distribute costs more equally since they consider social matters in their design. Therefore, in order to establish a water demand model based on the tariff structure, several aspects must be considered for both water companies and customers.

This study contributes to the water management literature as it relates to the environmental conservation of watersheds within an economic context of water supply. Zalewski (2015) presents a dichotomy between the approaches for water management of hydrologists and ecologists. He provides an integrated management methodology, highlighting elements anchored in both economic and environmental premises. However, the approach of hydrologists and ecologists focus on the supply side of water provision, disregarding the fact that this supply is due to the need of consumers, in other words, the demand. Therefore, this analysis considers the method of simultaneous equations. As the equations of supply and demand for water are interdependent, it may not be accurate or useful to analyze the results from isolated water demand or supply models. 
Given the importance of domestic consumption in an urban environment, a derivation curve for residential water demand is necessary for the implementation of any water policy. Furthermore, from a social-economic perspective, such policies often result in controversial consequences (Martins \& Fortunato, 2005; Arbués et al., 2010). Increased efforts to improve urban water management have focused on demand-side policies seeking to affect water use behaviors in order to rationalize its use.

In situations of water scarcity, resulting from an unexpected reduction in rainfall (increasingly unpredictable weather) for example, urgent measures to increase the water supply may not be viable since both the undertaking of engineering projects or the recovery of watersheds require time to ensure an increase in the water supply. In these cases, management acts on water demand through curbing measures, environmental education, and tariff price increase. However, such measures often do not achieve the expected results as they lack precise and quantitative knowledge of the factors that affect water demand.

Price-related policies are among several measures implemented to encourage a reduction in water consumption. However, the effectiveness of these policies depends on the price elasticity of consumption (Arbués et al., 2010). To this end, empirically investigating the urban water demand curve plays a key role. We calculate the sensitivity of demand to price changes.

Consumers' perception of water price, taking into account the tariff regime, is important to encourage the rationalization of water. One way to improve users' perception of the economic value of water is to use tariffs that reflect how much consumers of different income classes should pay for water.

Regarding the optimal water tariff, Bravo-Sánchez et al. (2019) warns of the consequences of the free market in the management of water resources, pointing out that this policy benefits a small group with economic power to the detriment of the community. Thus, in Brazil and in many Latin American countries, water legislation followed the Spanish model, where water is a public good and the entire community participates of the management, generating differentiated tariffs between different consumers (Bravo-Sanchez et al., 2019).

Consequently, when designing a model of water demand based on the tariff structure, these aspects must be taken into account as well as the water companies and the consumers' perspective. The variable conditions of water from demand model should provide consistent coefficients with reports on empirical experience of literature.

The area under study was Distrito Federal (DF), located in Brazil's central region. The Distrito Federal is one of the 27 federative units in Brazil and in its territory is located the city of Brasilia, capital of Brazil. It comprises an area of 5,787.784 $\mathrm{km}^{2}$, with a population of around 2,570,160 in 2010 (IBGE, 2010). It is a region characterized by high population density, equal to 444 inhabitants/ $\mathrm{km}^{2}$. The largest portion of the population lives in urban regions. The company responsible for the public supply service of water in Distrito Federal is Companhia de Saneamento de Brasília (CAESB).

In 2010, CAESB was serving around 2.3 million people - around $96 \%$ of the urban population. Among the residential, commercial, public, and industrial sectors that participate in water consumption, the residential sector is by far the largest 
consumer of water, accounting for $79 \%$ of the water consumption of the public supply system.

We aimed to test a hypothesis formulated based on national and international empirical papers regarding the magnitude of the effects triggered by variables associated with water demand. The parameters extracted allow us to evaluate demand responsiveness according to each category. Considering time-series data on the production system and the total value of tax revenues, customer income, and climate conditions, the residential water demand curve for the Distrito Federal was derived.

\section{Materials and methods}

\subsection{Data sources}

Data from the public supply system of the studied area was collected from CAESB, considering only the time dimension. In other words, we use monthly time-series data on water commercialization in the residential sector - total monthly income from water commercialization ( $\mathrm{R} \$ /$ month) and total monthly water consumption volume ( $\mathrm{m}^{3} /$ month). We divide the supply system consumption into two category: "standard residential" and "popular residential." This classification is used by CAESB to apply the monthly tariffs used to charge water and sewage services. Residential consumption units fall into these two categories, following the provisions of Article 7 of Decree No. 20,658 of September 30, $1999^{1}$, which establishes a score and classification according to the physical characteristics of the residence.

Consumption data and total income were considered separately by consumption zone, for both water use categories. Since water consumers are under a tariff system based on crescent blocks, disaggregated data for each consumption zones allow us to determine the price perceived by consumers and the average price effectively charged for the commercialized water. In these blocks, consumers are grouped by their consumption volumes.

The tariff regime consists of eight consumption blocks, in which the company, according to each block, applies a tariff. Then total income is determined using the tariff table. During the study period, total income values were adjusted based on December 2008, using monthly values of the Consumer Price Index (IGP - M) and calculated according to the Fundação Getúlio Vargas (FGV) criteria.

Other investigations using different data sources were performed to obtain representative variables of climate conditions as well as consumers' income. Weather conditions data, such as monthly average temperature and daily precipitation, were obtained from CPAC-EMBRAPA and the Instituto Nacional de Meteorologia (INMET). Employment index data, used as a proxy for consumer income, were obtained from Distrito Federal Employment and Unemployment Research (PED-DF).

\footnotetext{
${ }^{1}$ Decree No. 20,658, September 30, 1999, which regulates Law No. 442 of May 10, 1993, which provides for the classification of tariffs for water and sewage services of the Federal District and other measures. Available at: http://www.caesb.df.gov.br/_conteudo/Legislacao/Decretos/ Decreto20658.asp.
} 


\subsection{Water demand determiners specification}

Wooldridge (2002) states that time series show interdependence through time, or autocorrelation. In other words, the last observation of a series is related to its most recent historical records, and could show some trend over time. Since past events can influence future events, time is an important dimension in our data. Another characteristic is the frequency in which data is collected as many series present seasonal patterns.
The explanatory variables for water consumption were determined considering time-series data on the water volume consumed per block, total income per consumption block, consumer price index, urban population employment rates, and weather conditions. For each variable, we have 8 $\times 12=96$ monthly observations related to weather and consumers' social and economic conditions. In Figure 1, the time-series data used to obtain variables related to water consumption are presented. The flowchart gives the empirical model's variables and their collection method.

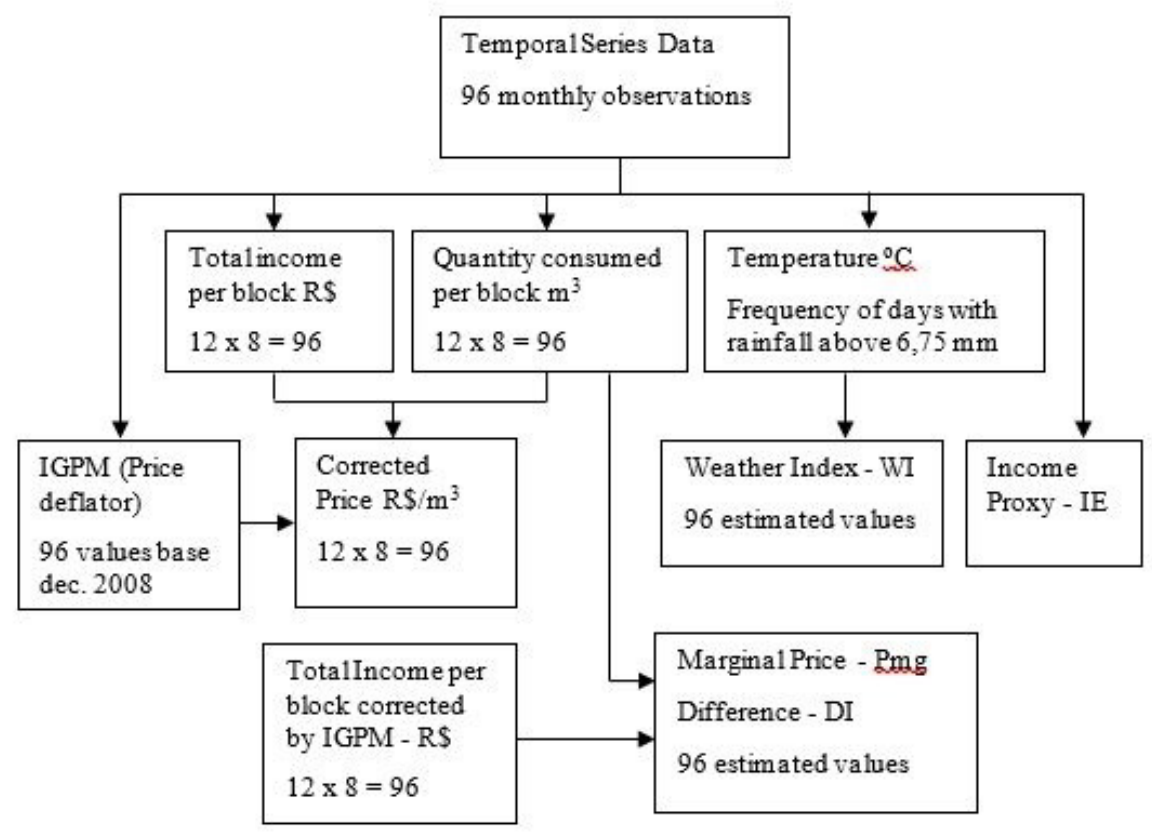

FIGURE 1 - Flowchart of time series samples and explanatory variables.

Note: The data are time-series referring to the variables that explain the water demand and cover the region of the Federal District, Brazil. The time-series are monthly from 2001 to 2008 , totaling a sample of 96 observations. 


\subsection{Price structure and block rates}

The water demand literature has focused on price specification and on estimation techniques to deal with the block pricing schemes commonly used by water companies. Early studies determined that the marginal price should be included when pricing is done based on a tariff structure in blocks. Furthermore, when using marginal price, a difference variable should be incorporated (Taylor, 1975; Nordin, 1976; Billings \& Agthe, 1980). The difference variable measures the income effect of the rate structure and is defined as the difference between what a household would pay if all units were charged at the marginal price and what they actually pay.

Given the complexity of the tariff structure in blocks, the price to which consumers respond remains controversial. Standard microeconomics theory stipulates that residential water consumers should respond to the marginal price for the next unit of water consumed, as well as the marginal price in each block below the final block of consumption (Olmstead et al., 2007; Strong \& Smith, 2010; Nataraj \& Hanemann, 2011).

Independent variables specified were marginal price and intra-marginal difference price. The marginal price is the amount charged by the last water consumer unity, while the difference explains fixed tariffs and intra-marginal income effects. In this study, we incorporate both variables in the model. The literature recommends including the Nordin specification (marginal price and difference variable) in the demand model. Nordin (1976) highlights that consumers not only react to the marginal price but also to the surplus variations due to changes in considers the price table as a whole on consumers' decision, capturing the income effect imposed by the tariff structure.

The inclusion of the marginal price and the variable difference allows us to analyze how the effects of an increase in tariffs charged to low-income and middle-income households influence the amount of water demanded by these users. That is, changes made in the tariffs charged to users affect the amount of water demanded by them. These statements are confirmed by the coefficient of the marginal price parameter. The interpretation is that an increase in the price of water may decrease the amount of water demanded in these two categories, but in a smaller proportion than the actual increase in water tariffs in the respective categories of consumption blocks. This finding is because consumers react more in the proximity of the block of the highest price, which is where the marginal change occurs. That is when the consumer decides for a small incremental adjustment in consumption that has already been made.

There is no consent in the literature whether is the average or marginal price that residential water consumers use to make their consumption decisions. This is important to capture the effect of price changes on consumer demand under block tariff structures (Nataraj \& Hanemann, 2011). Standard economic theory assumes that rational people make decisions at the margin, in other words, based on small incremental adjustments around the edges of an existing action. In the face of marginal changes, the rational decision-maker will execute a particular action if, and only if, the marginal benefit exceeds the marginal cost (Mankiw, 2014).

Therefore, several authors have used the marginal price to explain water demand: Foster \& 
Beattie (1981); Chicoine et al. (1986); Williams \& Suh (1986); Moncur (1987); Agthe \& Billings (1987); Nieswiadomy \& Cobb (1993); Andrade et al. (1995); Barkatullah (1996); Renwick \& Archibald (1998); Mattos (1998); Hoglund (1999); Rietveld et al. (2000); Higgs \& Worthington (2001); Garcia \& Reynaud (2004); Hoffman et al. (2006); Martínez-Espiñeira (2007) and Martins \& Fortunato (2005).

As the quantities in the lower blocks are sold at lower prices, an intra-marginal difference variable is introduced to suggest that the low-income category should have a more substantial subsidy when it changes to a higher consumption block, i.e., when there is an increase in the water tariff. Therefore, a positive variable difference points out that consumers actually pay more for water than they would pay if water were charged at the marginal price. Such a subsidy may be financed either by the government itself or through cross-subsidy, as it currently does for the lowest income groups. These aspects are justified in the text to reinforce the marginal price and the difference variable in a scheme of increasing rates in blocks, practiced by the water company.

Ordinary least squares (OLS) estimates of the marginal price and difference variables will be biased due to the endogeneity of marginal price, difference variable, and quantity of water used (Griffin et al., 1981). To overcome this hurdle, water demand studies use two-stage least squares (2SLS) and instrumental variables techniques to control for endogeneity issues (Agthe et al., 1986; Deller et al., 1986; Agthe \& Billings, 1987; Nieswiadomy \& Molina, 1989; Hewitt \& Hanemann, 1995; Höglund, 1999; Nauges \& Thomas, 2003). Structural equation estimation techniques are also used to estimate water demand under block rates and are especially useful for data that are limited to time-series observations (Hewitt \& Hanemann, 1995; Olmstead et al., 2007). Moeltner \& Stoddard (2004) estimate monthly water use as a function of marginal price, weather variables, individual customer characteristics, and time effects. They show that, by using monthly water use observations and marginal prices for individual customers instead of aggregated data, water use can exhibit strong seasonal patterns, which can aggravate simultaneity problems associated with block pricing if these patterns are not specified in the water demand model (Keeney et al., 2008).

In an attempt to avoid possible estimate biases in the relationship between price and consumed quantity, we recurred to the procedure developed by Taylor et al. (1981) and later tested by Billings (1982). Also used recently by Nataraj \& Hanemann (2011), Rinaudo et al. (2012) and Yoo et al. (2014), this type of methodology results in a linear approximation of the total water bill. The procedure used observed quantities and incomes to derive a marginal price and a constant intra-marginal difference for each tariff structure. The method proposes an artificial linearization of the tariff structure to derive instrumental variables for the marginal price and the intra-marginal difference.

The data using the Billings method was generated from the total income and commercialized water quantities, on eight consumption blocks, for the period from January 2001 to December 2008. Equation 1 provides 96 estimates for the marginal price (Pmg) and the difference variable (DI), determined monthly, from 96 monthly observations corresponding to total revenue (TR) and total quantity (TQ) in each block. As revenue and quantity data are distributed in this period, in 8 consumption blocks, 
there are 768 observations distributed in the period from January 2001 to December 2008. As a result, 96 regressions of quantities of water consumed on the revenues collected are determined each month.

Therefore, for the standard and normal residential categories, we estimate marginal price and the difference variable using the following equation:

Where:

$$
R T_{i j}=\alpha_{i}+\beta_{i}+Q T_{i j}+\varepsilon_{i}
$$

$\mathrm{RT}_{\mathrm{ij}}$ is the total income in $\mathrm{j}^{\text {th }}$ block $(\mathrm{j}=1,2, \ldots, 8)$ of the $\mathrm{i}^{\text {th }}$ month ( $\mathrm{i}$ $=1,2, \ldots, 96$ );

$\mathrm{Q}_{\mathrm{ij}}$ is the total consumed quantity of potable water in the $\mathrm{j}^{\text {th }}$ block $(\mathrm{j}=1$, $2, \ldots, 8)$ of the $\mathrm{i}^{\text {th }}$ month $(\mathrm{i}=1,2, \ldots, 96)$;

$\boldsymbol{\varepsilon}_{\mathrm{i}}$ is equal to the stochastic error in the $\mathrm{i}^{\text {th }}$ month;

$\boldsymbol{\beta}_{\mathrm{i}}$ is the total income inclination function value during the $\mathrm{i}^{\text {th }}$ month; $\boldsymbol{\alpha}_{\mathrm{i}}$ is the total income function intercept during the $\mathrm{i}^{\text {th }}$ month.

From January 2001 to December 2008, the values of the instrumental variables were estimated for each tariff structure: marginal price and instrumental difference. Incomes regressions regarding correspondent quantities were run according to the Equation 1 on both water user categories (standard and popular) using the statistical software Statistical Package for the Social Sciences (SPSS) version 15.0 for Windows.

\subsection{Weather}

Balling \& Gober (2007) stated that the domestic use of water is affected by weather variables. In general, water annual consumption increases during the drought season, periods of elevated temperatures, and low rainfall levels. The authors suggest that water consumption depends mostly on low air humidity, fall temperatures, and summer rainfall. Although temperature, rainfall and, drought season affect consumption, Balling \& Gober (2007) verified that their method response is relatively low to weather changes in areas where residential consumption is mostly to external activities like irrigation. This fact suggests that weather conditions and consumption are connected by complex behavior patterns, but are relevant to design policies for ore efficient water uses in urban zones.

Weather and other seasonal factors are measured in several ways, which include temperature (Gaudin, 2006), summer rainfall (Garcia \& Reynaud, 2004), and the number of rainy days (Hoffman et al., 2006). Studies show that the simple occurrence of rainfall creates a psychological impact. Therefore, the frequency of rainy days affects water demand more than rainfall quantity (Griffin \& Chang, 1991; Martínez-Espiñeira, 2003).

Simplified approaches to water demand assume that total water use consists of, on one hand, basic, and, on the other, seasonal use. The basic use of water is characterized by the amount demanded during a representative winter (Zhou et al., 2002). Moreover, previous studies characterize basic use as mainly to be internal use, which does not vary with climate (Maidment et al., 1985; Zhou et al., 2000).

Intuitively, demand for water is highly seasonal and dependent on climate and weather conditions. Exactly how to consider these variables is a challenging question; researchers continue to search for the best combination of weather variables to explain consumption patterns. The literature does not identify a preferred method for modeling weather variables, nor is there a consensus on what is more important: the monthly total precipitation, the number of precipitation events, or the time between rainfalls. More often, precipitation is found to be 
the most useful independent variable, but also value is found in measures of temperature. Furthermore, research is frequently constrained by the fact that only monthly household-level consumption data are available per month, whereas weather data exist in a daily frequency (Kenney et al., 2008).

Other studies have shown that the basic use was modeled as being representative of the winter use, based on the months of least use in a year. Even the correlation of baseline values with temperature and precipitation were not performed for residential water use. Although the relationship of baseline values with temperature and rainfall has not yet been performed for residential use (internal use), there is a need to investigate whether the basic use of water-use modeling is insensitive or climate-sensitive (Gibbs, 1978; Miaou, 1987).

In this sense, a climate index that relates the two variables in an aggregate way was employed, considering that the use of the two separate variables could cause bias in the estimation of the demand model since temperature and precipitation are correlated. Sarker et al. (2013) have established an analysis to see if "basic use," representative of indoor use, is insensitive to climate or whether "basic use" values can be representative of winter use (including gardening in other areas or cities) and sensitive to the weather.

Based on the above, we adopted a monthly weather index (WI) formulated by Griffin \& Chang (1991) as an independent variable. The WI implies that water demand behavior responds more to the number of rainfall days than to rainfall volumes and that temperature and the absence of rainfall interact. The WI variable accounts for the fact that months have a different number of days (Griffin \& Chang, 1991). The weather index can be determined from the frequency of rainless days during months; in other words, days with precipitation lower than $6.75 \mathrm{~mm}$ (Griffin \& Chang, 1991), multiplied by the maximum and minimum daily temperatures daily $\left({ }^{\circ} \mathrm{C}\right)$ monthly average:

Where:

$$
W I_{i}=\frac{\left(\operatorname{Tmax}_{i}+\operatorname{Tmin}_{i}\right)}{2} \times\left(1-F_{i}\right)
$$

$\mathrm{WI}_{\mathrm{i}}$ is the weather index during month $\mathrm{I}$,

$\mathrm{F}_{\mathrm{i}}$ is the monthly proportion of days with rainfall above $6.75 \mathrm{~mm}$,

$\mathrm{T}_{\max }$ is the average maximum daily temperature for the $\mathrm{i}^{\text {th }}$ month $\mathrm{I}$, and

$\mathrm{T}_{\min }$ is the average minimum daily temperature for the $\mathrm{i}^{\text {th }}$ month.

\subsection{Income}

Water demand must increase as income increases, similarly to any other normal good. Generally, income elasticity estimates are inelastic and with smaller magnitude, according to Garcia \& Reynaud (2004), Hoffman et al. (2006), Gaudin (2006), and Schleich \& Hillenbrand (2009). However, the tariff structure in crescent blocks can potentially affect the magnitude of income-elasticity (Worthington \& Hoffman, 2008).

Theoretically, estimating demand from micro-level data (disaggregated), taking into account the individual socioeconomic characteristics of households (particularly household income), is the preferred approach. In practice, however, attempts at the micro-level are limited since they require a large volume of data in the composition of representative samples as the characteristics of the various variables, included in the demand function, make it challenging to obtain microdata with the highest possible level of disaggregation.

As only time-series data were available, a proxy for income was chosen to capture its effects 
on the water demand. The unemployment factor index (UI) was used aiming to relate urban population employment level and water consumption in the studied area since the indicator reflects the socioeconomic status of the population in that area. The choice of the UI as a proxy for income has the advantage of not showing a seasonal pattern trough time when compared to other economic indicators (such as total retail sales index, calculated according to criteria of the Instituto Brasileiro de Geografia e Estatística - IBGE). The UI was obtained using the ratio between the number of registered employees and the size of the population in the studied area, multiplied by 100 (Departamento intersindical de estatística e estudos socioeconômicos - DIEESE, 2010).

There are some restrictions in using the aggregate variable UI. It does not allow us, for instance, to relate residential consumption with household income in a specific location or specific consumer group or period. Otherwise, Grafton et al. (2011) studied observations regarding income categories. They observed the effect of the price of water on household water consumption, estimating a model that allows for changes in price elasticity between different income groups. This model included an interaction term between a dummy variable for three income classes and the natural logarithm of price. The income categories were "low income," "middle income", and "high income."

On the other hand, the monthly UI measure reflects the rate of people employed compared with the economically active population. The UI variable represents the income for a large part of the population as well as the growth of the consumer market. The income gains obtained by people employed with or without a portfolio (civil and military statutory civil servants, for example), provide an improvement in access to various urban services, such as sanitary sewage, garbage collection, electric lighting, and especially water supply.

\subsection{Empirical model formulation}

The magnitude of the effect of price on the quantity of water demanded by consumers is indicated by the price elasticity of demand. In general, the water demand estimate is inelastic when it comes to prices since water has no substitutes for basic uses. On the other hand, inelastic values are due to low consumer perception levels of the tariff structure, when the water bill represents a small proportion of their income (Arbués et al., 2010; Yoo et al., 2014).

For a given municipality, water demand in a month can be expressed by Equation 3, which indicates that consumers adapt their behavior regarding water consumption according to price changes. Moreover, in the long term, consumers change their water consumption habits. Therefore, domestic water use is inversely related to the price of water.

$$
\operatorname{In} Q_{t}^{D}=\beta_{0}+\beta_{1} \operatorname{InPmg}_{t}+\beta_{2} \operatorname{InIE}_{t}+\beta_{3} \operatorname{InWI}+\beta_{4} \operatorname{InDI} I_{t}+\varepsilon_{t}
$$

The dependent variable $Q_{t}{ }^{D}$ represents the quantity of water consumed from the supply system. The independent variables are $\mathrm{Pmg}_{\mathrm{t}}$ (water marginal price), $\mathrm{IE}_{\mathrm{t}}$ (employment index used as consumers' income proxy), $\mathrm{WI}_{\mathrm{t}}$, the weather index used to capture water consumption seasonality, $\mathrm{DI}_{t}$ (intra-marginal difference) and $\varepsilon_{\mathrm{t}}$ (the error term, which represents other factors omitted from the model that might estimate water consumption. 
The estimated parameters are $\beta_{0}, \beta_{1}, \beta_{2}, \beta_{3}$ and $\beta_{4}$, which express how variables affect water demand. The effect is expected to be negative for the marginal price $\left(\beta_{1}<0\right)$, positive for consumer income $\left(\beta_{2}>0\right)$, positive for seasonality $\left(\beta_{3}>0\right)$, and positive for the intra-marginal difference $\left(\beta_{4}>\right.$ $0)$. The estimated model used a logarithmic form due to the possibility of obtaining elasticity directly from the coefficients. All hypotheses were evaluated using the p-values for the coefficients at the $10 \%$ significance level.

In the residential water demand model, the existence of simultaneity between price and quantity is discussed extensively in the literature. The simultaneity issue occurs when endogenous regressors are correlated with the error term. Since price and quantity are dependent on the tariff amount, a correlation exists between the price of water and the stochastic error term (Andrade et al., 1995).

A fundamental aspect of any model of demand or supply is its identification. Such aspect influences on obtaining coherent and consistent results from an empiric point of view. On a typical demand specification, prices are endogenous. Hence, prices observed result from consumer-producer interactions. This property requires distinguishing between price changes and the quantity caused by the shift in the supply curve resulting from the shift in the demand curve. Consequently, "traditional" methods to estimate demand generate price coefficients that are less negative than what they are in reality. Therefore, to identify the demand, it is necessary to obtain estimates free of inconsistency.

In a simultaneity relation, the dependent variable (Y) is determined according to the explanatory variables $(\mathrm{X})$, and some explanatory variables are affected by Y. In contrast to unique equation models, simultaneous equations models estimate parameters without considering information in other equations in the system. When a model is estimated by OLS, the identification condition is that each explanatory variable is not correlated with the error term. Given the interdependence between the stochastic error and the endogenous explanatory variable (or variables), OLS is inappropriate for estimating an equation in a simultaneous equation system ( $\mathrm{Gu}-$ jarati, 2010).

Unique equation methods were used to correct for simultaneity between price and consumption. More specifically, 2SLS. This method is appropriate for the simultaneous equation model context, providing biased but consistent estimators (Gujarati, 2010). Based on the instrumental variables, it is possible to identify (or estimate consistently) the parameters of a simultaneous equation model (Wooldridge, 2002).

The identification problem is the possibility to obtain parameters for a structural equation from coefficients estimated from the reduced form. If that can be achieved, it is stated that the equation is identified. If it is, we have a non-identifiable or sub-identified model (Gujarati, 2010). In our case, the demand function is identifiable, as the $P E$ variable (Eq. 4) shifts the supply without affecting the demand equation. For each $P E$ variation and none error, the demand equation is delineated (Wooldridge, 2002).

The existence of a non-observed demand shifter (the error term) renders the demand equation estimates wrong. However, the estimators will be consistent since the PE variable is not correlated to the error. To specify two simultaneous equations, the drinking water supply function, specified in Equation 4 below, is fundamental for identifying 
the simultaneous equation system and applying the 2SLS method.

Where:

$$
\operatorname{In} Q_{t}=\gamma_{\mathrm{o}}{ }^{{ }}+\gamma_{1} \operatorname{InP} E_{t}+\varepsilon_{t}
$$

$\mathrm{Q}_{\mathrm{t}}{ }^{\circ}$ is the dependent variable, representing the water offer quantity during the $\mathrm{t}^{\text {th }}$ month;

$\mathrm{PE}_{\mathrm{t}}$ is the average price of water charged by the company, corresponding to consumption blocks during the $\mathrm{t}^{\text {th }}$ month, and $\varepsilon_{\mathrm{t}}$ is the error term.

For this simultaneous equation system, there are two endogenous variables: demanded water quantity and marginal price of water $(\mathrm{M}=2)$. There are five exogenous variables in the equation system: the intercept, DI, IEP, IC, and PE $(\mathrm{K}=5)$. Equation 3 has an endogenous variable, the marginal price $(\mathrm{m}=1)$, so $\mathrm{M}-\mathrm{m}=2-1=1$, in other words, one unknown variable to be defined. In Equation 3, there are four exogenous variables: the intercept, DI, IEP, and IC $(\mathrm{k}=4)$. Therefore, $\mathrm{K}-\mathrm{k}=5-4=1$ resulting in the same number of unknown variables and relations, which result in an exactly identified equation (Gujarati, 2010). As for the identification of Equation 4, there is one endogenous variable $(m=1)$, so $M-m=2-1=1$. On the other hand, there are two exogenous variables: the intercept and $\mathrm{PE}$ $(\mathrm{k}=2)$. Thus, $\mathrm{K}-\mathrm{k}=5-2=3$, implying that equation 4 is over identified (Gujarati, 2010).

Essentially, 2SLS involves two successive applications of OLS aiming to "remove" the stochastic explanation variable ( $\left.\mathrm{Pmg}_{\mathrm{t}}\right)$ from the error term. This goal is reached by executing a two-phase procedure. According to Gujarati (2010), the two-phase procedure provides consistent estimators; therefore, they converge to their real values while increasing indefinitely ${ }^{2}$. The first phase consists of conducting a regression on the reduced form of the endogenous variable $\mathrm{Pmg}_{\mathrm{t}}$ with all pre-determinant variables on the system, estimating values for $\mathrm{mg}_{\mathrm{t}}$ according to the following equation:

$$
P m g_{t}=\pi_{0}+\pi_{1} P E_{t}+\pi_{2} I E_{t}+\pi_{3} W I_{t}+\pi_{4} D I_{t}+\varepsilon_{t}
$$

In the second phase, $\mathrm{Pmg}_{\mathrm{t}}$ estimates replace the values of $\mathrm{Pmg}_{\mathrm{t}}$ in the structural equation, and then the OLS regression is conducted according to the following model seen next:

$$
\operatorname{In} Q_{t}=\beta_{0}+\beta_{1} \operatorname{InPmg}_{t}+\beta_{2} \operatorname{InIE}_{t}+\beta_{3} \operatorname{InWI}_{t}+\beta_{4} \operatorname{InDI}_{t}+\varepsilon_{t}
$$

The hypotheses for obtaining appropriate estimates in a regression model of simultaneous equations are the non-existence of problems of multicollinearity, heteroscedasticity, specification, and autocorrelation. The evaluation of multicollinearity was based on the Variance Inflation Factor (VIF), heteroscedasticity, and specification using White's test (1980) and autocorrelation by the " $d$ " statistic of Durbin-Watson.

\section{Results and discussion}

The analysis of water demand from time series data present more limitations than when using cross-section data for consumers or locations. Firstly, the analysis does not make use of relevant social-economic characteristics of consumer groups (such as individual income, residential composition, and water use habits). Secondly, the parameters estima-

${ }^{2}$ This highlights the fact that in small samples, estimated values for endogenous variables will probably be correlated with the error term. However, such a correlation disappears as the sample size tends to infinity. Therefore, in small samples, the 2SLS proceeding might result in a tendentious estimate. 
ted from cross-section data provide more realistic estimates of demand responses on the variations of conditioning factors.

Arbués et al. (2003) highlight that time series should be used carefully since the data usually consists of short time series and exhibit few variations of the water prices. Therefore, combining time-series data with cross-sectional data provides more advantages. Considering these limitations, data compatibility, and the time dimension as well, the analysis of variables affecting residential water demand was restricted to economic, social-economic, and weather factors. As stated previously, the explanatory variables we used are the marginal price (Pmg), the intra-marginal difference (DI), the weather (WI), and the employment index (UI), as a water consumer proxy.

The estimated parameters for the explanatory variables allow us to analyze residential water demand behavior in both categories. Parameter estimates are presented in Equations 7 and 8 below, for the standard and popular categories, respectively. Coefficients were determined from simultaneous equations (4), (5) and (6) using the regression analysis in the two-stage least square method (2SLS). In each equation, the $t$ coefficients of each explanatory variable, and their $p$ values, adjusted coefficient of determination ( $\mathrm{R}^{2}$ adjusted) and Variance Inflation Factor (VIF) were highlighted.

- Normal Category

$$
\operatorname{In} Q_{t}=2.37-0.18 \operatorname{In} \widehat{\operatorname{Pmg}_{t}}+0.54 \operatorname{InIE} E_{t}+0.07 \operatorname{InWI}+0.07 \operatorname{InDI} I_{t} \varepsilon_{t}
$$

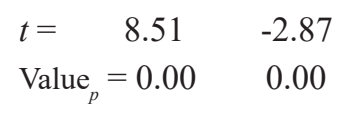

$$
\begin{array}{lccl}
\mathrm{VIF}= & 2.56 & 3.73 & 1.41 \\
\mathrm{~N}=96 & \text { R2 adjusted }=0.75 & \mathrm{~F}=67.41 & d=2.20
\end{array}
$$

\section{- Popular Category}

$\operatorname{In} Q_{t}=0.91-0.15 \operatorname{InPmg}_{t}+0.85 \operatorname{InIE}_{t}+0.04 \operatorname{InWI}_{t}+0.06 \operatorname{InDI}_{t}+\varepsilon_{t}$

$$
\begin{aligned}
& \begin{array}{llllll}
t= & 1.97 & -1.76 & 15.37 & 1.13 & 4.89
\end{array} \\
& \begin{array}{lllll}
\text { Value }_{p}=0.05 & 0.08 & 0.00 & 0.06 & 0.00
\end{array} \\
& \begin{array}{lllll}
\mathrm{VIF}= & 1.46 & 4.65 & 1.07 & 5.13
\end{array} \\
& \mathrm{~N}=96 \mathrm{R} 2 \text { adjusted }=0.92 \quad \mathrm{~F}=257.52 d=1.83
\end{aligned}
$$

In the standard and popular categories, the selected variables explain $75 \%$ and $92 \%$ of water consumption variation, respectively. Reinforcing the relevance of the explanatory variables, the value of the F statistic confirms that the set of variables used in the model was significant at the 5\% significance level for both categories. The test for the significance of regression using the $\mathrm{F}$ statistic factor determines whether there is a linear relationship between the dependent variable and the regressive variables. Thus, a high $\mathrm{F}$ value indicates rejection of the null hypothesis, i.e., there is a significant linear relationship between the explanatory variables and the dependent variable. VIF values of each explanatory variable were lower than 10 , showing little collinearity among the explanatory variables. In both categories, the Durbin-Watson Test $(d)$ does not reject the hypothesis of a lack of positive and/ or negative autocorrelation at the 5\% significance level. Analogous to the Durbin-Watson test, the White test indicated the absence of heteroscedasticity and specification problems at the $5 \%$ level in the estimated models. 
The price elasticity of water demand for both sub-groups shows little difference in magnitude. In other words, both groups react similarly to an increase in water tariffs. The price elasticity of the demand price for the "standard" category is approximately 0.18 and is significant at the 5\% significance level. However, for the residential "popular" category, the demand price elasticity equals 0.15 and is also significant at the 5\% level.

For the "popular" category, the estimated elasticity is about 0.15 ; this indicates a $1 \%$ increase in the marginal price of water results in a $0.15 \%$ decrease in the total demand. For the "normal" residential class, the estimated elasticity is around 0.18 , which means that a $10 \%$ increase in price would result in a $1.8 \%$ decrease in water consumption. The results of the econometric analysis (Eq. 7 and 8) show that the marginal price of water is a statistically significant factor. Price elasticities are estimated to be -0.18 and -0.15 , which are well within the range of values reported in recent case studies (Worthington \& Hoffman, 2008; Schleich \& Hillenbrand, 2009 Rinaudo et al., 2012). Other factors have the signs we expected. Water use is positively correlated with the weather indicator, and this relationship is statistically significant. Furthermore, in the "popular" residential category, the price elasticity is more inelastic than in the "normal" residential category. In the area studied, the tariff system is different for the two categories, which might cause a higher effect on the water bill of users in the "standard" category.

On the other hand, in the two categories analyzed, the answer to water demand is conditioned to the urban population employment level. In the popular residential category (classified as low-income), the increase in demand quantity is proportionally higher than the increase observed in the "standard" residential category (average and high-income). This shows that there is a suppressed demand in the "popular" residential category. These results are in line with the view that access to water should be a human right, given the relationship between public health problems and poor water quality and distribution (Cini et al., 2019). According to the authors, "water should not be reverted to a strictly monetary value, because it holds a vital value".

The demand elasticity of the intra-marginal difference is positive and rises above 1 in both categories analyzed. The positive value for difference-elasticity indicates that the consumer is paying a lower value than if they were charged at the marginal price. Therefore, the value for elasticity-difference reflects the implicit subsidy on the tariff structure. In both evaluated categories, the variable difference value was significant for $p$ values lower than $5 \%$ probability levels, with elasticity-difference levels equal to 0.07 , for the "standard" residential category and 0.06 for the "popular" category. In these categories, the income effect when moving from one water consumption block to another determines the water consumption in the two classes of users. Therefore, policies aiming to encourage consumption will be effective, since users benefit from a subsidy.

Income-elasticity for water demand is approximately 0.54 and 0.85 , on standard and popular residential classes, respectively. Such values were significant for $p$ values under $5 \%$. Therefore, increasing $1 \%$ on the urban population employment rates (here expressed by the employment index) in the studied area increases water consumption by around $0.54 \%$ in the "standard" residential category. In the popular category, a $1 \%$ increase 
in urban population employment level increases consumption by around $0.85 \%$. In the standard class, particularly, the estimated value is close to what is obtained for developed countries, highlighting the income-elasticity values found by García-Valiñas (2005) and Schleich \& Hillenbrand (2009), which were 0.58 and 0.46 , respectively. Considering that water is a common good, its consumption is proportionally lower to consumer's income increases. The estimated values found reinforce the theory that income-elasticity decreases when consumer income increases, observing an increase in its magnitude of around $57 \%$ in the popular category, regarding the normal category. However, Yoo et al. (2014) estimate the income elasticity of water demand in Phoenix, Arizona to be about 0.04 . This value shows that a $1 \%$ increase in median household income between 2000 and 2008 increased water use by $0.04 \%$ in that time period. A comparison between these parameters allows us to verify the lower end of the range of income elasticities already reached. Then, it is corroborated that high-income households are less sensitive to water price increases than lower-income households are. This is as expected when the water bill represents a much smaller proportion of monthly expenditure for high-income than for low-income households.

As for weather influence on water consumption, it is stated that the standard residential category shows a demand elasticity regarding seasonality equal to 0.07 , significant at the $5 \%$ significance level. This result was already expected because the weather index represents the multiplicative interaction between temperature and lack of rain in their effects on the water demand. Since the standard category consists of users from average to high income, it exhibits a greater consumption pattern, mostly because of non-essential uses. On the other hand, the popular category is less sensitive to seasonal variations in the areas studied (0.04 of change, insignificant for $p$ values under the $5 \%$ level). In this category, seasonality does not influence water consumption. It is important to highlight that measures of seasonality effects, considering different user categories, can favor water conservation policies.

In situations of water scarcity, for example, resulting from an unexpected reduction in rainfall (increasingly unpredictable weather variables), immediate measures to increase the water supply may not be viable, since both the undertaking of engineering projects or the recovery of water basins require time to ensure an increase in the water supply.

In these cases, management acts on water demand, through rationing measures, environmental education, and tariff price increase. However, such measures often do not achieve the expected results since they are elaborated without precise and quantitative knowledge of the factors that affect water demand. Therefore, the work is in accordance with what Zalewski (2015) considers as a holistic vision for water resources management.

Therefore, the elaboration of a water resources management plan, whether through intervention in the supply of water, considering engineering actions or conservation of the environment, should also consider actions that affect the demand for water. The effectiveness of measures of rationing, environmental education, modification of tariffs prices, among others, depends on quantitative studies on the demand for water. The elaboration and trust in public policies for water demands a wide range of information, derived from participation of several 
actors and clearly defined rules and processes (Brugué et al., 2018).

\section{Conclusions}

Generally, coefficients estimated by 2SLS using the $\log$ - $\log$ model see eye to eye with those found empirically and reported in the literature about water demand. The strength of the results found, using the log-log functional form, indicates that endogenous water price variables (for example, the marginal price) were eliminated by the adopted method (2SLS). Water demand in the area studied was inelastic in terms of price, in both the standard and popular categories.

The magnitude of the estimated parameters for the water demand model reflect determinant factors influence the degree and explain the differences between water consumption in the two consumer categories. Even with little difference between the values of the magnitude of elasticity in both categories, estimates suggest that the popular residential category is more sensitive to water pricing policies since it is less inelastic to price. The rise or fall in the price of water has little effect on its consumption. Results suggest that the water tariffs historically practiced by CAESB seek the public interest and not a profit maximization.

The approach of hydrologists and ecologists focus on the factors that only affect the supply of water, disregarding the fact that this supply is due to the need of the consumers, in other words, the demand. Therefore, the analysis considered the method of simultaneous equations, since the equations of supply and demand of water are interdependent, and it may not be accurate or useful the results from isolated analyzes of the demand or supply of water.

To confirm these results, it would be interesting to perform investigations using spatial data instead of data limited to time series and the aggregated level. From this perspective, it would be possible to further explain the relationship between water consumption and age groups, water use habits, individual income, and other social-economic and behavior variables.

Since the demanded quantity in the popular category is less sensitive to price variations (in other words, the demand is more inelastic) when compared to the normal category, the theory that certain basic demand uses are inelastic is reinforced. However, whereas non-essential uses are increasing (such as water fonts, pools, and irrigators), this characteristic is associated with the normal category, the demand becomes less inelastic regarding price.

All variables tested had an inelastic effect on water demand, demonstrating that water consumption is little influenced by its tariff, consumers' income and climatic issues. Thus, changes in these variables will have little impact on water consumption.

\section{References}

Agthe, D.; Billings, R. Equity, price elasticity, and household income under increasing block rates for water. American Journal of Economics and Sociology, 46(3), 273-286, 1987.

Agthe, D.; Billings, R.; Dobra, J.; Rafiee, K. A simultaneous equation demand model for block rates. Water Resources Research, 22, 1-4, 1986.

Andrade, T.; Brandão, A. S. P.; Lobão, W. J. A. Silva, S. L. Q. Saneamento urbano: a demanda residencial por água. 
Pesquisa e Planejamento Economico, 25(3), 427-448, 1995.

Arbués, F.; Garcia-Valinas, M. A.; Martinez-Espiñeira, R. Estimation of Residential Water Demand: A State-of-art Review. The Journal of Socio-Economics, 32, 81-102, 2003.

Arbués, F.; Villanúa, I.; Barberán, R. Household size and residential water demand. Australian Journal of Agricultural and Resource Economics, 54, 61-80, 2010.

Balling, R. C.; Gober, P. Climate variability and residential water use in the city of Phoenix, Arizona. Journal of Applied Meteorology and Climatology, 46(7), 1130-1137, 2007.

Barkatullah, N. OLS and instrumental variable price elasticity estimates for water in mixed-effects model under multiple tariff structure. Sydney: National Library of Australia, n. 226, 1996.

Billings, B. R. Specification of block rate price variables in demand models. Land Economics, 58(3), 386-394, 1982.

Billings, B. R.; Agthe, D. E. Price elasticities for water: a case of increasing blockrates. Land Economics, 56(1), 73-84, 1980.

Bravo-Sánchez, J. M.; Naranjo-Ramírez, G. del C.; Hidalgo-Carrasco, R. A. La Política de Agua de Chile: una radiografía histórica, legal y administrativa a la gestión del agua en manos del mercado neoliberal. Agua y Territorio, 13, 43-54, 2019.

Brugué, Q.; Gelis, J. F.; Güemes, C. Confianza democrática y proceso de formulación de políticas públicas: el caso de la política hídrica de Cataluña. Revista de Sociologia e Política, 26(67), 129-152, 2018.

Chicoine, D. L.; Deller, S. C.; Ramamurthy, G. Water demand estimation under block rate pricing: a simultaneous equation approach. Water Resources Research, 22(6), 859-863, 1986.

Cini, R. de A.; Rosaneli, C. F.; Fischer, M. L. Direito humano à água e bioética: revisão da literatura latino-americana com foco na realidade brasileira. Agua y Territorio, 14, 105-114, 2019.

Deller, S.; Chicoine, D.; Ramamurthy, G. Instrumental variables approach to rural water service demand. Southern Economic Journal, 53(2), 333-346, 1986.
DIEESE. Departamento intersindical de estatística e estudos socioeconômicos. Pesquisa de Emprego e Desemprego no Distrito Federal, 2010. Available in: <http://www.dieese. org.br/ped/brs/pedbrs0610.pdf>. Access on: nov. 2016.

Foster, H. S.; Beattie, B. R. Urban residential demand for water in the United States: Reply. Land Economics, 57(2), 257-265, 1981.

Garcia, S.; Reynaud, A. Estimating the benefits of efficient water pricing in France. Resource and Energy Economics, 26(1), 1-25, 2004.

García-Valiñas, M. A. Efficiency and equity in natural resources pricing: A proposal

for urban water distribution services. Environmental \& Resource Economics, 32(2), 183-204, 2005.

Gaudin, S. Effect of price information on residential water demand. Applied Economics, 38, 383-393, 2006.

Gibbs, K. C. Price variable in residential demand models. Water Resources Research, 14(2), 15-18, 1978.

Grafton, R. Q.; Ward, M. B.; Hang, T.; Kompas, T. Determinants of residential water consumption: Evidence and analysis from a 10-country household survey. Water Resources Research, 47, 1-14, 2011.

Griffin, A. H.; Martin, W. E.; Wade, J. C. Urban residential demand for water in the United States: comment. Land Economics, 57, 252-256, 1981.

Griffin, R. C.; Chang, C. Seasonality in Community Water Demand. Western Journal of Agricultural Economics, 16(2), 207-217, 1991.

Gujarati, D. N. Econometria Básica. Rio de Janeiro: Elsevier-Campus, 4. ed., 2010.

Hewitt, J. A.; Hanemann, W. M. A Discrete/Continuous Choice Approach to Residential Water Demand Under Block Rate Pricing. Land Economics, 71(2), 173-192, 1995.

Higgs, H.; Worthington, A. Consumer preferences and charging options in a large urban municipality: A case study. Public Works Management and Policy, 5(3), 209-207, 2001.

Hoffman, M.; Worthington, A. C.; Higgs, H. Urban water demand with fixed volumetric charging in a large munici- 
pality: The case of Brisbane, Australia. Australian Journal of Agricultural and Resource Economics, 50(3), 347-359, 2006.

Höglund, L. Household demand for water in Sweden with implications of a potential tax on water use. Water Resources Research, 35(12), 3853-3863, 1999.

IBGE. Instituto Brasileiro de Geografia e Estatística. Brasília, 2010. Available in: <http://www.ibge.gov.br/cidadesat/topwindow.htm>. Access on: dec. 2016.

Jacobi, P. R.; Empinotti, V. L.; Schmidt, L. Water Scarcity and Human Rights. Ambiente \& Sociedade, 19(1), 1-5, 2016.

Kenney, D. S.; Goemans, C.; Klein, R.; Lowrey, J.; Reidy, K. Residential Water Demand Management: Lessons from Aurora, Colorado. American Water Resources Association, 44(1), 192-207, 2008.

Klaiber, H. A.; Smith, V. K.; Kaminsky, M., Strong, A. Measuring price elasticities for residential water demand with limited information. Land Economics, 90(1), 100-113, 2014.

Maidment, D.R.; Miaou, S.P.; Crawford, M. M. Transfer function models of daily urban water use. Water Resources Research, 21(4), 425-432, 1985.

Mankiw, G. N. Principles of Microeconomics. United States: Cengage Learning, Inc, 7. ed., 2014.

Martínez-Espiñeira, R. Estimating water demand under increasing-block tariffs using aggregate data and proportions of users per block. Environmental and Resource Economics, 26(1), 5-23, 2003.

Martínez-Espiñeira, R. An estimation of residential water demand using cointegration and error correction techniques. Journal of Applied Economics, 10(1), 161-184, 2007.

Martins, R.; Fortunato, A. Residential water demand under block rates a Portuguese case study. Grupo de Estudos Monetários e Financeiros, 9, 1-19, 2005.

Mattos, Z. P. B. Uma análise da demanda residencial por água usando diferentes métodos de estimação. Pesquisa e Planejamento Econômico, 28(1), 207-224, 1998.

Miaou, S. P. Metropolitan's Daily Water Use-Analysis and Forecasting. Technical Report. Los Angeles, CA, USA:
Metropolitan Water District of Southern California, 1987.

Moeltner, K.; Stoddard, S. A Panel Data Analysis of Commercial Customers' Water Price Responsiveness Under Block Rates. Water Resources Research, 40, 1-9, 2004.

Moncur, J. Urban water pricing and drought management. Water Resources Research, 23(3), 393-398, 1987.

Nataraj, S.; Hanemann, W. M. Does Marginal Price Matter? A Regression Discontinuity Approach to Estimating Water Demand. Journal of Environmental Economics and Management, 61, 198-212, 2011.

Nauges, C.; Thomas, A. Long-run study of residential water consumption. Environmental and Resource Economics, 26(1), 25-43, 2003.

Nieswiadomy, M.; Cobb, S. Impact of pricing structure selectivity on urban water demand. Contemporary Policy Issues, 11(6), 101-113, 1993.

Nieswiadomy, M.; Molina, D. J. Comparing Residential Water Demand Estimates under Decreasing and Increasing Block Rates Using Household Data. Land Economics, 65(3), 280-289, 1989.

Nordin, J. A. A proposed modification of Taylor's demand analysis: comment. The Bell Journal of Economics, 7(2), 719-721, 1976.

Olmsted, S. M.; Hanemann, W. M.; Stavins, R. N. Water Demand under Alternative Price Structures. Journal of Environmental Economics and Management, 54(2), 181198, 2007.

Renwick, M.; Archibald, S. Demand side management policies for residential water use: Who bears the conservation burden? Land Economics, 74(3), 343-359, 1998.

Rietveldt, P.; Rouwendal, J.; Zwart, B. Block rate pricing of water in Indonesia: An analysis of welfare effects. Bulletin of Indonesian Economic Studies, 36(3), 73-92, 2000.

Rinaudo, J. D.; Neverre, N.; Montginoul, M. Simulating the impact of pricing policies on residential water demand: a Southern France case study. Water Resources Management, 26(7), 2057-2068, 2012.

Sarker, R. C.; Gato-Trinidad, S.; Imteaz, M. Temperature and Rainfall Thresholds corresponding to water consump- 
tion in Greater Melbourne. In: Annals of the Australia 20th International Congress on Modelling and Simulation. Adelaide, Australia, 1-6 December, 2013.

Schleich, J.; Hillenbrand, T. Determinants of residential water demand in Germany. Ecological Economics, 68(6), 1756-1769, 2009.

Strong, A.; Smith, V. K. Reconsidering the economics of demand analysis with kinked budget constraints. Land Economics, 86(1), 173-190, 2010.

Taylor, L. D. The demand for electricity: a survey. The Bell Journal of Economics, 6(1), 74-110, 1975.

Taylor, L. D.; Blattenberger, G. R.; Rennhack, R. K. Residential energy demand in the United States. Lexington, Massachusetts: Electric Power Research Institute, Inc, 1981.

White, H. A Heteroscedasticity consistent covariance matrix estimator and a direct test of heteroscedasticity. Econometrica, 48, 817-818, 1980.

Williams, M.; Suh, B. The demand for urban water by customer class. Applied Economics, 18(12), 1275-1289, 1986.
Wooldridge, J. M. Introdução a Econometria: uma abordagem moderna. São Paulo: Thomson learning, 2. ed., 2002.

Worthington, A. C.; Hoffman, M. An empirical survey of residential water demand modeling. Journal of Economic Surveys, 22(5), 842-871, 2008.

Yoo, J.; Simonit, S.; Kinzig, A. P.; Perrings, C. Estimating the Price Elasticity of Residential Water Demand: The Case of Phoenix, Arizona. Applied Economic Perspectives and Policy, 36(2), 333-350, 2014.

Zalewski, M. Ecohydrology and hydrologic engineering: regulation of hydrology-biota interactions for sustainability. Journal of Hydrologic Engineering, 20(1), 1-14, 2015.

Zhou, S. L.; Mcmahon, T. A.; Walton, A; Lewis, J. Forecasting daily urban water demand: a case study of Melbourne. Journal of Hydrology, 236, 153-164, 2000.

Zhou, S. L.; Mcmahon, T. A.; Walton, A.; Lewis, J. Forecasting operational demand for an urban water supply zone. Journal of Hydrology, 259(1-4), 189-202, 2002 